\title{
Montage, Von Rad en Belydenis
}

P M Venter

Departement Ou-Testamentiese Wetenskap (Afd A)

Universiteit van Pretoria

\begin{abstract}
Montage, Von Rad and Confession

Following Sailhamer's practice of using the term 'montage' as a hermeneutical key for understanding the canon of the Old Testament, this term is investigated and it is shown that Von Rad used it as a technique in his works on the Hexateuch. It is proposed that the same technique can be used in modern theologies and in the use of confessions.
\end{abstract}

\section{INLEIDING}

Sailhamer gebruik onder andere die begrip montage as 'n hermeneutiese sleutel om die Ou Testament as kanon te lees en te verstaan. 'n Nadere ondersoek van hierdie begrip bring aan die lig dat dit wesenlik dieselfde tegniek is wat Von Rad in die tradisiehistoriese groeiproses van die Heksateug veronderstel. Soos daar in die montage deur die jukstaponering van entiteite nuwe metafore gevorm word wat uitdrukking gee aan bepaalde ideologiese beskouings, is die Heksateug volgens Von Rad gevorm deur verskillende belydenisse wat oor die loop van tyd saamgevoeg is om belydenisse te vorm waarin die geloofsoortuigings van Israel uitgedruk is. Hierdie teologiese metafore vorm die kanon waarop die Christendom en later die Christelike kerk se belydenisse geskoei is.

Kennis van die tegniek van montage, insig in die wyse waarop Von Rad hierdie tegniek ingespan het om die Heksateug te verstaan om by 'n teologie van die Ou Testament uit te kom, kan van waarde wees vir die teologisering en belydenisvorming van die kerk. Dit kan die kerk in 'n postmoderne tyd help om nie net sogenaamde teenstrydige gedeeltes in die kanon jukstaponerend saam te lees en so tot ' $n$ basiese teologiese metafoor vir die kanon te kom nie, maar dit kan ook daartoe lei dat die kerk ou en nuwe belydenisse in ' $n$ dialektiek met mekaar kan stel van waaruit weer ' $n$ omvattende nuwe teologiese metafoor en belydenis kan groei.

\section{MONTAGE BY SAILHAMER}

Sailhamer gebruik die begrip montage in sy Introduction to Old Testament theology: A canonical approach (1995). Hy kies daarin om met die gefikseerde en die finale vorm van die kanon te werk. Die eindvorm ('shape') is vir hom van deurslaggewende be- 
lang. Daar is ' $n$ '.. hermeneutics and semantics of that shape' (Sailhamer 1995:239). Die strukture van daardie eindvorm kan egter nie teologies reg verstaan word as daar nie ook aandag gegee word aan die maniere waarop dit geskep is nie. Die eindvorm moet ook diakronies gelees word. Hierdie diakroniese lyn moet egter vanuit die teks self bepaal word. Die volgorde en die rangskikking van die materiaal van die bestaande teks dui self aan in watter volgorde die teks gevorm is.

Die bepaalde volgorde en rangskikking het in hoofsaak deur drie tegnieke tot stand gekom: deur intertekstualiteit, deur redaksionele verwerking en deur kontekstualiteit. Onder intertekstualiteit verstaan Sailhamer dat die Pentateug eerste geskryf was en dat die res van die Hebreeuse kanon intertekstueel daartoe bygevoeg is. Die dele van die Profete en die Geskrifte vorm uitbreidinigs op die Wet en moet in samehang daarmee gelees word. Ook die redaksionele verwerking van die materiaal bied ' $n$ hermeneutiese sleutel vir die verstaan van die kanon. Elke fase daarvan het 'n bepaalde kanoniese betekenis. Die redaksionele werk was telkens doelbewuste pogings om bepaalde fundamentele opvattings oor die Hebreeuse Bybel te vestig. Onder kontekstualiteit verstaan Sailhamer wat die filmmaker Sergei Eisenstein onder montage verstaan. Die bepaalde volgorde en rangskikking van die boeke vorm jukstaposisies wat teologiese temas skep wat nie in die afsonderlike dele aanwesig is nie.

Hierdie begrip van kontekstualiteit of eerder montage (om enige verwarring met die begrip kontekstualisering te vermy) verdien verdere aandag. Sailhamer gee nie in sy werk enige teoretiese begronding vir hierdie term wat hy gebruik nie. Die teoretiese onderbou daarvan word daarom vervolgens uitgewerk met die oog op beter en breër toepassing van die begrip.

Sailhamer se verduideliking dat een of ander vorm van montage aan die werk was by die beslissing oor die volgorde van boeke in die kanon, moet ook verder uitgewerk word. Sy opmerking dat die boeke van die Vroeëre en Latere profete '... are arranged to be read in chronological sequence ...' (Sailhamer 1995:250) herinner aan Von Rad. Die gedagte dat twee gedeeltes naas mekaar gevoeg is om die idee van historiese opeenvolging te wek, herinner aan Von Rad se beskouing dat die Heksateug nie die werklike opeenvolging van historiese gebeure weergee nie, maar eerder ' $n$ teologiese metafoor van God se heilsgeskiedenis met Israel. Daar moet dus by Von Rad nagegaan word of hy nie met iets werk wat op montage neerkom nie. Ook die gevolge daarvan dat 'n tipe montage-tegniek by Von Rad tot 'n teologie van die Ou Testament lei, moet verder deurdink word.

\section{MONTAGE AS LITERERE FENOMEEN}

Montage is 'n konstruksieprinsipe. Dit is die tegniek van '... naast elkaar plaatsen van verschillende beelden waaruit een centraal thema ontstaat' (Renders 1983:29). Die 
kunstenaar skep 'n nuwe tema of idee '... by the combination or association of two or more ideas he already has into a new juxtaposition in such a manner as to discover a relationship among them of which he was not previously aware' (Sparke \& McKowen 1970:2).

Montage verskil van intertekstualiteit en collage. In literêre intertekstualiteit word gedeeltes van ander literatuur, soos aanhalings, begrippe, of idees, opgeneem in die werk wat geskep word. Dit word integraal deel van die nuwe teks. Die dele wat opgeneem word verloor ook hulle oorspronklike betekenis en identiteit. In collage word fragmente of groter gedeeltes uit verskillende werke bymekaar gevoeg op so 'n manier dat 'n gedeelte van die vorm en iets van die oorspronlike betekenis nog behoue bly. In montage bly die gehéél van die oorspronklike vorm, betekenis én die selfstandigheid van die dele volledig behoue. Deur jukstaponering en relasiestelling van die twee of meer selfstandige dele wat opgeneem word, ontstaan daar 'n semantiese omraming wat 'n nuwe tema skep in terme waarvan die samestellende entiteite voortaan verstaan moet word. Daar ontstaan '... een alomvattende inclusiviteit' (Renders 1983:29) wat al die konstituerende dele in dialektiese interrelasie met mekaar stel en hulle die onderdele maak van 'n groter en oorkoepelende geheel.

Twee tegnieke staan in die letterkunde teenoor mekaar: montage en mise en scène. Die laaste is waar die verteller '... can tell his story in a logical, chronological manner, beginning at the beginning and, when he comes to the end, stopping' (Albrecht 1992: 23). In montage kom die jukstaponering van die gedeeltes neer op 'n verbreking van die mise en scène. Die lineêre handelingslyn word opgehef sodat die diakroniese handelinge uiteenval in parallele kleiner of groter sinkroniese segmente. Dit is die tegniek '... to fragment the narrative into its constitutive elements and then to arrange these elements, disregarding logic and chronology, somewhat in the manner of a cubist painting' (Albrecht 1992:23). Die segmente staan dus nie meer, soos in die lineêre handelingslyn, kousaal tot mekaar nie, maar is sinkronies met mekaar gerangskik om in hulle geheel 'n enkele fase in die handelingslyn te vorm. Daar ontstaan '... a dialectic between adjacent shots '... (Albrecht 1992:283). Hierdie stolling in die verloop lei tot 'n tipe statiese of sikliese tydsbelewing (vgl Renders 1983:31). Daar ontstaan 'n multidimensionaliteit ('... een veelheid van momentane indrukken - Renders 1983:32) van waaruit daar inklusief en allesomvattend gekyk word na wat daar gebeur. Daar ontstaan '... een alomvattend wereldbeeld' (Renders 1983:32), 'n omvattende perspektief wat Eisenstein 'n 'global image' (vgl Holladay 1993:254) noem. 'n Holistiese perspektief word geskep wat deur die konstituerende dele afsonderlik en saam onderbou word. Die konstituerende dele skep saam die omvattende wêreldbeeld en verkry elkeen afsonderlik ' $n$ betekenis in terme van die oorkoepelende siening. 
Die sinkroniese newestelling van die segmente van die montage beteken hoegenaamd nie dat hulle sinoniem gestel word nie. Inteendeel, om allesomvattend en multidimensioneel te wees, staan die segmente in dialektiese konflik met mekaar. Vir Eisenstein is die essensie van die montage juis '... every structural possibility of regulating the heterogeneous ...' (Sánchez-Biosca 1990:285). Selfs ook by Brecht, waar die konflikterende aspek van die segmente plek moet maak vir die gestus, die bydraende houding wat uit elke segment as selfstandige gedeelte van die geheel spreek, om die fabel, die strekking van die komposisie, uit te beeld, lê die segmente nie op een vlak nie, maar vertolk elkeen 'n bepaalde aspek van wat die montage deur sy dele tot uitdrukking wil bring (vgl Mueller 1987, veral bladsye 474-475).

Deur die jukstaponering van die konstituerende gedeeltes van die montage word 'n bepaalde perspektief geskep sonder om dit pertinent in woorde te omskryf. Dit gebeur deurdat daar in die jukstaponering van die dele 'n konflik of patos ontstaan waarvan die kyker of leser skerp bewus word wanneer die twee of meer tonele voor hom/haar verbyskuif. Hy/sy word daartoe meegevoer om uit die kontras 'n bepaalde omvattende begrip te ontdek wat alles in verhouding met mekaar sien. Dit is die leser wat die betekenis ontdek. 'Meaning, which resides somewhere between the two paired poems, is created by the reader, who is forced constantly to revise, to re-read the one poem in light of its counterpart' (Albrecht 1992:25; my beklemtoning). Eisenstein se definisie van patos is dan ook dat die patos alles is wat die bioskoopganger daartoe voer om verras uit sy sitplek uit op te spring, sy posisie te verlaat en homself te transendeer en dinge vanuit ' $n$ ander hoek te begin sien (vgl Sánchez-Biosca 1990:287). Deur die dialektiese konflik word die kyker/leser daartoe beweeg om 'n omvattende opinie te vorm wat as 'n perspektief by hom/haar vassteek. Dit is 'n blikrigting wat tegelyk in, maar tegelyk ook agter of selfs tussen die segmente van die teks lê, 'n soort surplus betekenis wat by die waarnemer gevorm word in die proses van belewing.

Deur die indruk wat die sinkroniese 'tydloosheid' van die montage skep, word aan die perspektief wat geskep is, 'n soort universaliteit verleen. Dit verkry iets van 'n universele en tydlose gelykenis (vgl Barnet, Berman en Bruto se formulering: '... rather as a simile does ...', aangehaal by Renders 1983:29). Sánchez-Biosca (1990:287) praat van '.. transition from the dramatic order of the situation to the metaphorical order ....' Die patos wat ontstaan '... has a poetic dimension; it belongs to the paradigm, to the vertical order of the metaphor' (Sánchez-Biosca 1990:287). Dit het 'n metaforiese karakter waar daar deur die gelykstelling van twee (of meer sake) 'n derde dimensie van die werklikheid aangedui word wat altwee sake insluit maar tegelyk transendeer omdat dit ' $n$ universele, inklusiewe uitspraak wil maak, wat alleen by wyse van 'n gelykenis/metafoor gestel kan word. 
Die gebruik van montage om op metaforiese wyse 'n wêreldbeeld oor te dra, is integraal deel van die aard van die wêreldbeskouing wat gehuldig word. Die onderlig. gende paradigma van hierdie perspektief is die wesenlike dialektiek van bestaan. By intertekstualiteit gaan dit om die oortuiging dat alle taaluitings vasgevang sit in die dialektiek van bestaan, in die polifonie van dialektiese uitsprake. Alles en almal is voortdurend interaktief op mekaar ingestel. Die basiese beskouing is ook hier dat die montage se jukstaponering waarheidsgetrou die werklikheid van die konflikterende wêreld, waarin alles en almal interaktief teenoor mekaar staan, weerkaats. Die eksistensiële situasie van die mens in die wêreld is juis dat hy binne relasies staan met alles wat hom omring. Die montage dring egter nog verder deur en probeer deur middel van die metafoor wat hy daarstel, 'n geheel-omvattende paradigma bied van waaruit die geheel beskou moet word.

Hierdie aanbieding van 'n totaliteitsiening stem tot op groot hoogte ooreen met aspekte van Smuts se model van 'dinamiese holisme' (vgl Venter 1991). Afsonderlike eenhede word bymekaar getrek om groter gehele te vorm. Deur kreatiewe sintese word voortdurend nuwe kombinasies gevorm wat oor funksies en eienskappe beskik wat nie in hulle dele teruggevind kan word nie. Deur die proses van montage word al groter mutasies geskep. Gejukstaponeerde gedeeltes word weer met ander gejukstaponeerde gedeeltes gejukstaponeer. So word metafore naas ander metafore gestel en daaruit telkens al meer omvattende metafore uitgebou wat al groter gehele intrek in 'n al meer omvattende holistiese paradigma.

\section{MONTAGE, METAFOOR EN TEOLOGIE}

Prichard het in haar doktorale tesis van 1990 aangedui dat metafore ook met genre en met teologie te doen het. Sy sluit by die gedagte aan dat daar konflik in die wêreld is vanweë die veelvormigheid en veelvuldigheid van sake. Die waarheid is nie iets wat gegee is nie, maar iets wat ontdek moet word. Sy is van oortuiging:

'... that the world is orderable rather than ordered, that through our perceptions, descriptions, rediscriptions, and interpretations of the world, we shape our own reality, that all creative activity, whether academic, artistic, or quotidian is undertaken in an effort to order and interpret an ambigious world'.

(Prichard 1990:3-4) 
Taal, kuns, literatuur en teologie is '.. ordering lenses through which reality is perceived and interpreted' (Prichard 1990:3). Wat deur hierdie aktiwiteite gebeur, is dat daar gepoog word om sin te gee aan 'n wêreld van veranderlikes en teenstrydiges. Die teks wat afgelewer word en die interpretasie wat dit van die werklikheid gee, is die resultaat van 'n konflik tussen verskillende vlakke van betekenis, tussen teenstrydighede, die interaksie tussen eie ervaring en ander interpretasies, hetsy van ouer tekste, hetsy van eietydse uitsprake.

Ook teologiese tekste is wesenlik 'n kreatiewe poging om die konflikterende wêreld te orden en te interpreteer. Die inhoud wat teologiese tekste aanbied, staan egter nie los van die vorm waarin dit aangebied word nie. Daar is ' $n$ '... interplay of form and content in the production of meaning' (Prichard 1990:2). Teologiese tekste moet met 'n 'oop einde' hermeneuties verstaan word - ' $\ldots$ one that struggles to understand texts within changing and ambiguous contexts' (Prichard 1990:2). Nie net die inhoud van die teks moet binne die konteks van 'n voortgaande proses wat orde in teenstrydighede probeer bring, gesien word nie maar ook die vorm waarin daardie inhoude aangebied word, moet binne die konteks van konflik en interaksie met ander interpretasies en teologiese literatuur beskou word.

Om die aard van die teologiese werk te verstaan, moet dit met die aard van die metafoor en genre vergelyk word. Al drie werk met die interaksie tussen die oue en die nuwe. Innovering is by al drie afhanklik van die dinamiese verhouding tussen die nuwe en die oue. Al drie beweeg binne die kontinuiteit van die bekende verlede en die onbekende toekoms. Teologie beweeg altyd binne ' $n$ interpreterende konteks. As sosiale, kulturele en historiese wese beweeg die interpreteerder altyd vanuit bestaande teologiese uitsprake na 'n nuwe wêreld met al sy konflikterende gegewens. Hy moet altyd binne 'n veranderende konteks soek na betekenis, na 'n manier om dit wat gesê is opnuut betekenisvol te maak. Prichard (1990:9) sê agter McFague aan: 'As we demythologize and deconstruct, as we preside over the obsolescence of religious imagery, we must also remythologize, construct, reconstruct, and remodel'.

Hierdie 'her-mitologiseer' beteken eintlik her-metaforiseer. Nuwe kennis moet altyd in terme van wat reeds bekend is, geformuleer word. Nuwe konsepte word slegs begryp as hulle in vergelyking met of kontras tot bestaande konsepte gesien word. Dit kom daarop neer '.. that at the most basic level we think metaphorically' (Prichard 1990:10). Om te teologiseer, is om in terme van wat alreeds in metafore gesê is, verder te metaforiseer. In aansluiting by die bekende metafore word in die konteks van die nuwe en onbekende na betekenis gesoek, en dit word in die metaforiese vorm gegiet wat in interaksie met die metafore van die verlede staan. Omdat konsepte en metafore '... radically contextual ...' (Prichard 1990:10) is, verloor hulle hulle effektiwiteit as die konteks verander. Hulle word soos geldstukke wat afgeslyt is. Elke nuwe konteks vereis daarom nuwe metafore warin ordenende konsepte uitgedruk word. 
Ook die literêre vorms waarin teologiese konsepte ge-artikuleer word, is kontekstueel gebonde. Die geykte genre patrone waarin die teoloog sy kreatiewe uitset uiteensit, bestaan ook in 'n veranderende konteks. Soos wat die konteks verander, verloor die bepaalde stelwyse sy effektiwiteit en word dit noodsaaklik om die teologiese betekenis wat die teoloog vir een tyd gevind het in 'n ander tyd op ' $n$ ander manier in te klee.

Om saam te vat: wat Prichard betoog, is dat die stelwyse van teologiese tekste, die konsepte en metafore wat dit gebruik en die teologiese betekenis wat dit aanbied, binne 'n konteks gesien moet word van singewing aan 'n wêreld wat voortdurend verander en deur konflikterende gegewens die teoloog uitnooi om sin daarvan te maak. Die raaklyne met montage, soos dit hier bo uiteengesit is, kom duidelik na vore. Die montage met sy metaforiese karakter, jukstaponeer twee (of meer) sake om daardeur 'n derde dimensie van die werklikheid aan te dui. Hierdie metafoor sluit altwee sake in en transendeer dit tegelyk om 'n universele en inklusiewe uitspraak te maak. Dit lê op dieselfde terrein as die teologiese werk, wat met genre en metafoor werk. Die montage met sy metafoorvorming swawelstert ineen met die teologie wat aan die hand van genre 'n teologiese blikpunt wil ontwikkel as 'n sinvolle visie op die wêreld van sy tyd.

\section{VON RAD}

\subsection{Teologie, Gattung en Metafoor}

Die oorvleueling tussen montage en teologie word duidelik wanneer na Von Rad se hantering van die Ou Testament gekyk word. Hy probeer teologiese betekenis vir sy eie tyd vanuit die gegewens van die Bybel vind. Daarvoor maak hy gebruik van 'n kombinasie van vier oorspronklik selfstandige denkmodelle. Omdat geskiedenis in elkeen van hulle ' $n$ sentrale rol speel, kan hulle tipeer word as '... das verheißungsgeschichtliche, das überlieferungsgeschichtliche, das heilsgeschichtliche und das sprachgeshichtliche ...' (Oehming 1985:20). In die werk van Von Rad word hierdie vier modelle met mekaar verweef en saam gebruik.

Hy gebruik hierdie kombinasie van metodes om by ' $n$ teologie van die Ou Testament uit te kom. Hy probeer die metafore van die Ou Testament peil en in aansluiting daarby en interaksie daarmee sy eie teologiese metafoor van die hele Ou Testament uitbou. Ten opsigte van die Heksateug neem hy die standpunt in wat later met sy naam verbind sou word: Israel het tydens verskillende kultiese byeenkomste 'n belydenis oor die wonderbare dade van God voorgedra. Op grond van die ervarings wat die volk deurgemaak het, is hierdie belydenis telkens hernieu. Die kultiese agtergrond het met tyd op die agtergrond geraak en die belydenis is binne verskeie ander kontekste uit- 
gespreek. Historiese oorlewerings het dus ontstaan wat van geslag tot geslag verder vertel is. 'n Kort historiese credo het in kleinformaat die Heksateug ten grond gelê. Te midde van verskillende uitbreidings is die basiese formule van hierdie credo steeds gehandhaaf. Uit hierdie belydenis het eventueel die eerste ses boeke van die Bybel ontwikkel waarin Israel van God se wonderbaarlike dade in die geskiedenis vertel. Die basiese elemente van die belydenis het bestaan uit die bevryding uit Egipte, die inname van die beloofde land en die besetting van die land. Hierdie kernoorlewering is nog terug te vind in Deuteronomium 26:5b-29, 6:20-24 en Josua 24:2b-13. Dit kom in vryer vorm ook voor by die kultusliriek van 1 Samuel 12:8, Eksodus 15, Psalms 105, 78,135 en 136. Aan hierdie kernbelydenis is later elemente uit die Sinaitradisie gevoeg (vgl Neh 9:6 en Ps 106).

Die.proses waarin hierdie belydenis uitgebou is, kom op dieselfde neer as montage. Al gebruik Von Rad nêrens die begrip montage nie, beskryf hy in wese 'n proses wat op montage neerkom. Die credo's wat volgens hom gebruik is en deur neweskikking in groter literêre werke uitgebou is tot selfstandige teologieë, is niks anders as montagegevormde teologiese metafore waarin die bekende gebeure interpreteer is en as belydenis op die eie tyd betrek is nie. In terme van Prichard se tesis is Von Rad se teologie 'n metafoor wat in ' $n$ belydenisgenre gegiet is wat by die Bybelse genre aansluit. Ook hy maak gebruik van die neweskikking (montage) van teologieë uit die ou en ook die Nuwe Testament om 'n teologiese model daar te stel wat as teologiese paradigma kan dien vir die kerk van sy dag.

\subsection{Historiese konteks}

Von Rad se werk moet teen die agtergrond van die geskiedenis van Duitsland gesien word. Die uitwerking van die kultuurprotestantisme van die $19 \mathrm{e}$ eeu was dat baie Protestante in Duitsland vatbaar was vir die opwellende golf van nasionalisme tydens die eerste paar dekades van die twintigste eeu. Die groepe van 'Deutsche Christen' (vgl Bakhuizen van den Brink \& Dankbaar 1968:222) wat gevorm is, was bekend vir hulle simpatie met die nasionaal-sosialisme. Hulle verkondig 'n Germaanse Christendom van die Nordiese ras en die wedergeboorte van die Duitse volk geld as 'n vorm van Goddelike openbaring. Dit was ook hulle kenmerk dat '... het "Joodse" Oude Testament erkenden zij niet of nauwelijks als heilige Schrift en Jezus Christus was als Zoon Gods geen Jood“ (Bakhuizen van den Brink \& Dankbaar 1968:223). Von Rad het dit as die uitdaging van sy lewe aanvaar om hierdie houding teenoor die Ou Testament en die '... völkischen und rassischen Ideen sich entwickelden Antisemitismus und dem heraufkommenden Nationalsozialismus ...' (Preuß 1991:7) teen te werk. Hy kom egter 
nie heeltemal los van sy tydsgees nie: '... doch ist sein Buch über das Gottesvolk im Deuteronomium unbewusster Ausdruck des überschwenglichen Gefühls nationalen Bewußtseins in Deutschland' (Crenshaw 1979:162).

\subsection{Kerugma en belydenis}

Von Rad se verdediging van die Ou Testament, sy strewe om dit relevant te maak vir die kerk van sy dag met al sy negerende tendense, sy verset teen die opsplintering van die Ou Testament in onsamehangende bronne en sy oortuiging dat die Ou Testament self, eerder as sistematiese teoloë, die teologie van die Ou Testament moet bepaal '... führt Von Rad zu der grosse "Entdeckung” von Bekenntnissen, die später zum Ganzen des Hexateuchs entfaltet wurden' (Crenshaw 1979:26). In sy soeke na die ' $\ldots$ am meisten entsprechenden Methodik einer AT-Theologie' (PreuB 1991:13), besluit Von Rad op 'n teologie wat '... die Zeugniswelt des AT erfassen, [und] nicht eine systematisch geordnete Glaubenswelt bieten' (PreuB 1991:14). Sy program is '... Israels eigene Bekenntnisse den Inhalt der Theologie bestimmen zu lassen' (Crenshaw 1979: 164). In sy Theologie des Alten Testaments stel Von Rad dit as sy tese dat die Ou-Testamentiese teologie besig moet wees met dit wat Israel self van God bely het. Dit is die navorser se opdrag om '... von Dokument zu Dokument ... nach der jeweiligen kerygmatischen Intention zu fragen' (Von Rad 1969:118). Vandaar kom die alombekende uitspraak van Von Rad: 'Die legitimste Form theologischen Redens vom Alten Testament ist deshalb immer noch die Nacherzählung' (Von Rad 1969:134-5). Crenshaw (1979:27) som Von Rad soos volg op:

Durch ständiges Lesen des Textes, durch das er sich ganz in den Dienst am Wort stellte, entdeckte Von Rad etwas Einzigartiges im alten Israei: die Notwendigkeit für Israel, sein Selbstverständnis immer aufs neue zu formulieren. Die volle Bedeutung und die Geschichte dieser Bekenntnisse des Glaubens an die Führung durch Gott zu erhellen, widmete Von Rad sein Leben.

In sy artikel 'Das formgechichtliche Problem des Hexateuch' van 1938, tipeer Von Rad die inhoud van die Heksateug met die terme 'Glaubenssätze' (Von Rad 1961:10), '... ein credo ... das die Hauptdaten der Heilsgeschichte rekapituliert' (Von Rad 1961:10). In sy latere Theologie bestempel hy die Heksateug as die 'entfaltete Bekenntnis Israels' (Von Rad 1969:318). Hierdie kultiese belydenis was geen ad hoc literêre skepping nie, maar was in 'n '... fest geprägte Form verwendet, die nur zu 
unbedeutenden Freiheiten Spielraum ließ' (Von Rad 1961:15). Die Heksateug is volgens hom as 'n geheel volgens die Gattung van die Credo ingeklee. Dit is 'n uitbouing van die kerncredo wat in Deuteronomium 26:5b-9 voorkom. Selfs hierdie kerncredo dra al die betrokke kentekens en eienskappe van 'n belydenis. Die kort oorsig oor die hoof gebeure van die heilsgeskiedenis wat daarin voorkom, vorm die raamwerk van die hele Heksateug waartoe dit uitgebou is.

\subsection{Kanonbeskouing}

'n Standpunt wat Von Rad gehuldig het, wat volgens Crenshaw (1979:168) nooit aanklank by ander gevind het nie, is sy teorie dat die credo eerder aan die begin as aan die einde van kultiese gemeenskappe staan. Ander navorsers het dit eerder as die afsluitende hoëpunt aan die einde van 'n lang sakrale proses gesien. Von Rad (1961:13) praat reeds van die kerncredo as '... einer schon kanonisch gewordene Form der Heilsgeschichte ...' Die manier waarop die heilsgeskiedenis in herinnering geroep word, is nie lukraak nie, maar is '.. eine Spiegelung der kanonischen Form, in der sich die Vorstellungen des Glaubens bewegten' (Von Rad 1961:13). Daar was vir Von Rad (1961:15) 'n 'kanonische(n) ... Bild der Heilsgeschichte'. Die gedeelte van Eksodus 19:1 tot Numeri 10:10 is 'n oorleweringskompleks wat '... in die kanonische Darstellung der Heilsgeschichte eingefügt worden [ist]' (Von Rad 1969:201). Die Deuteronomistiese geskiedenis is bygevoeg by die Pentateug, die '... schon in früher Zeit kanonisch gewordenen Heilsgeschichte' (Von Rad 1969:318; my beklemtonings). Wat eventueel uit die oorpronklike credo's sou uitgroei tot 'n grootse credo in die vorm van die Heksateug, is in Von Rad se terme die uitbouing van 'n reeds kanoniese belydenis tot ' $n$ omvattende gestruktureerde belydenis wat as kanon dien. Die gedagte dat die $\mathrm{Ou}$ Testament nie eers later kanoniek geword het nie, maar ' $n$ kanoniese uitbouing is van belydenisse wat reeds kanoniek was, open die weg vir 'n dinamiese beskouing van die geskiedenis van die kanonwording (vgl Venter 1987:12-24).

\subsection{Metaforisering en her-metaforisering}

Hierdie belydenisse was aan verskillende plekke verbind waar die kultus bedryf is '.. wo sich die Glaubensgemeinde öffentlich religiös betätigt ...' (Von $\operatorname{Rad} 1961: 28)$. Dit is onderskeidelik by die nuwejaarsfees, by die verbondsvernuwingsfees by Sigem en by die wekefees by Gilgal in die feesvierings geïnkorporeer. Met tyd het 'n proses van 'Spiritualisierung' (Von Rad 1961:58) ontstaan waarin die belydenisse uit hulle kultiese omgewing losgemaak is. 
Die opvallende van die oorleweringsproses wat hierop volg is '... daß Israel in jeweils neuer Situation die alten Tradition nicht einfach fallengelassen und durch neue ersetzt hat. Vielmehr hielt Israel durch seine Geschichte hindurch an alten Traditionen fest, aktualisierte sie aber im Lichte neuer Heilssetzungen Jahwes je und je neu und anders' (Oehming 1985:25). Daar was by Von Rad 'n '... Erkenntnis eines dem Alten Testaments immanenten Traditionsgesetzes: die ständige Neuinterpretation des Alten im Lichte neuer Heilssetzungen' (Oehming 1985:26). 'n Charismaties-eklektiese proses speel hom af van 'Einschmelzung des Alten in den Horizont der Gegenwart' (Oehming 1985:26). 'n Situasiebepaalde Vergegenwärtigung vind voortdurend plaas waarin die ouer tradisie behou word, maar in die lig van nuwe omstandighede verstaan word. Dit was 'n proses wat volgens Crenshaw vir Von Rad twee (1979:23) elemente gehad het: die '... konstanten Element, dem geschichtlichen Credo, und einen variablen Element, der Ausformung, der äusseren Gestalt'. Die konstante (die tradisie) word voortdurend aangevul met nuwe belydenisse. Op die bestaande materiaal is laag vir laag materiaal bygevoeg om vir elke tyd 'n belydenis te vorm: 'denn jeder Zeit war es aufgegeben, diese Sätze jeweils in der gemäßen theologischen Form auszusprechen und sich anzueignen' (Von Rad 1969:318). Dit kan volgens Oehming (1985:25) verstaan word in terme van 'n lig wat voortdurend van posisie verander, sodat die hoek waaruit die lig op die voorwerp val, veroorsaak dat daar telkens ander kontoere na vore kom. Dit is die proses van metaforisering en her-metaforisering wat hier bo by Prichard aangetoon is.

\section{6 'n Bonte mosaïek}

Wat vir Von Rad in hierdie proses opvallend was, is die bonte geskakeerdheid van die materiaal wat in hierdie proses bymekaar uitgekom het. Dit is vir hom 'n potpouri van verskillende getuienisse. Daar kan slegs daarvan gepraat word as van '... einer Mehrzahl Von vershiedenen und verschiedenartigen Offenbarungsakten' (Von Rad 1961: 128). Die aartsvadergeskiedenis is 'n 'bunte Erzählungsmosaik' (Von Rad 1969:181) wat uit velerlei orspronklike selfstandige oorlewerings bestaan. In die vertelling van die Rietseegebeure is ouer en jonger belydenisse en teologiese konsepte saamgevoeg om die heilsgeskiedenis waarmee Israel se geskiedenis begin het, uit te beeld. Die gedeelte van Eksodus 19:1 tot Numeri 10:10 is vir hom 'n samestelling van die wyduiteenlopendste materiaal met die 'grössten Unterschiede' (Von Rad 1969:201) waarin daar tevergeefs na 'n verbindende teologiese lyn gesoek kan word. Deuteronomium is '... ein kunstvolles Mosaik von vielen Predigten über die verschiedensten Gegenstände' (Von Rad 1969:234). 
Hierin is die '... verschiedensten Überlieferungen - historische, kultische, juristische - zusammengelaufen, und von ihnen wurde diese ganze weitschichtige Material in jenes grosse schematisierte Gesamtbild von dem Volk Israel hineingestellt ...' (Von $\operatorname{Rad}$ 1969:234).

\subsection{Vernuftige komposisies}

Von Rad gaan ook in op die tegniek waarmee hierdie materiaal bymekaar gevoeg is: 'Von Rad wunderte sich über die Art, in der Israel disparate berlieferungen zusammentrug und sie zu neuen Überlieferungen umformte, die in veränderte geschichtliche Situationen hinein sprachen' (Crenshaw 1979:164). Dit is vir hom duidelik '... daß allein schon die Zusammenordnung und literarische Verarbeitung des ungeheure weitschichtigen Überlieferungsmaterial eine theologische Leistung von höchsten Rang war ... (Von Rad 1969:129). Von Rad sien nie hierdie samevoeging van die materiaal as iets wat oor geslagte lank stelselmatig gegroei het nie. Die versameling van die Jahwis is volgens sy standpunt 'n literêre skepping wat doelbewus op een bepaałde stadium gedoen is: 'Die Verbindung ist rein literarisch vollzogen ...' (Von Rad 1961:61). Ook die latere samevoeging van die Elohis- en Priester-materiaal aan die Jahwis is ' $n$ 'rein literarischer Vorgang' (Von Rad 1961:82). Anders as latere navorsing wat die geloofsgemeenskap as bron van die komposisies sien, sien von Rad dit as die werk van ' $n$ individu. As '... freie Wagnis des Jahwisten' (Von Rad 1961:61) het hy doelbewus besitnemingstradisies en Sinaïoorlewerings bymekaar gevoeg.

\subsection{Montage by Von Rad}

Wanneer daar nader ingegaan word op die beskrywing van Von Rad hoe hierdie proses van samevoeging van disparate materiaal tot groter gehele hom afgespeel het, is die ooreenkoms met die tegniek van montage oorweldigend. Von Rad gebruik nêrens self die term nie en gee ook geen blyke dat hy die term ken nie. Die proses wat hy beskryf is egter presies dieselfde saak. Dit is veral die terminologie wat hy gebruik en die beklemtoning daarvan, dat die materiaal wat gebruik word, reeds selfstandige komposisies was wat in hulle samevoeging ' $n$ nuwe perspektief geopen het wat in die definisie van montage, soos dit hierbo uiteengesit is, inpas.

-Reeds in 'Das formgechichtliche Problem des Hexateuch' van 1938, kom Von Rad se montage-agtige benadering na vore in sy beskouing oor die invoeging van die Aartsvaderverhale by die res van die Jahwis se werk. Veral in die Josefsverhaal is dit vir hom duidelik '... wie der Jahwist nicht allein und ausschließlich auf die Konstruktion einer einzigen theologische Linie bedacht ist' (Von Rad 1961:67). Hy slaag daarin om 
die eenhede wat hy versamel het '... ein relatives Eigenleben ...' (Von Rad 1961:67) te laat geniet, maar hulle nogtans in '... eine letzte innere bindung aller seiner Stoffe an den tragenden theologischen Grundgedanken ...' (Von Rad 1961:67) saam te snoer.

Die werk van die Jahwis is volgens hom twee selfstandige tradisies met elkeen ' $n$ eie tema wat hier in een werk bymekaar gevoeg is: 'Die Landnahmeüberlieferung bezeugt Jahwes Gnadenwillen; im Mittelpunkt der Sinaitradition hingegen steht Jahwes fordernder Rechtswille' (Von Rad 1961:61). Von Rad beskryf die verbinding van die twee tradisies as 'n 'Hereinnahme': 'Durch die Hereinnahme der Sinaiüberlieferung bekam also der einfache soteriologische Grundgedanke der Landnahmetradition eine kräftige und heilsame Unterbauung' (Von Rad 1961:62). Hoewel hy van die 'Hereinnahme' van die een tradisie in die ander praat, is dit vir hom 'n suiwer literêre 'Verbindung' wat iets nuuts skep. Die samevoeging van twee bestaande selfstandige tradisies lei tot die tot standkoming van 'n nuwe teologiese metafoor waarin die inhoud van beide tradisies opgeneem is. Dis nie net die Landnahmetradition wat 'n Unterbaung deur die Sinaïtradisie ondergaan nie, maar die besitnemingtema self wat nou te staan kom '... unter dem Schatten der Gottesoffenbarung vom Sinai ...' (Von Rad 1961:62). Elkeen van die twee temas funksioneer voortaan: die een in terme van die ander om 'n nuwe teologiese metafoor daar te stel. Sy redenasie volg basies die patroon van montage-vorming waarin twee selfstandige eenhede in hulle samestelling 'n nuwe tema vorm.

Die Jahwis plaas 'n eie teologiese stempel op die werk wat hy versamel het. Hy neem nie net sy materiaal weg uit die kultiese sfeer nie, maar verplaas dit teologies na die gebied van die historiese. Sy bedoeling was om '... das Credo, jenes alte Bild der Heilsgeschichte, in völligerer, weitausgebauter Gestalt vor seinen Zeitgenossen zu entfalten' (Von Rad 1961:77). Hy gebruik 'n ouer beeld van die heilsgeskiedenis en werk dit verder uit deur die samevoeging van sy materiaal om so 'n teologie uit te bou oor die werking van God in die geskiedenis. Om dus aktueel te wees vir sy eie tyd, om in terme van wat hier bo gesê is, ' $n$ teologiese metafoor vir hulle aan te bied, maak hy gebruik van die parallelstelling, die montage, van bestaande tradisies. Deur sy montage ontwikkel hy sy teologiese metafoor oor God en die geskiedenis. Hy maak so ouer materiaal belydend aktueel vir ' $n$ latere tyd.

In sy Theologie des Alten Testaments, waarvan die eerste deel in 1957 verskyn hẹt en die tweede deel in 1960, met 'n aansienlike herbewerking met die vyfde uitgawe van deel een in 1966 en van die tweede deel met die vierde uitgawe in 1965, hou Von Rad nog steeds by hierdie benadering. Daar is volgens hom geen logiese samehang tussen die dokumente wat in die Heksateug en elders in die OuTestament byeengebring is nie. Die enigste logika agter die verbinding van die materiaal is die van 'geschichtliche 
Überlieferung' waar dit gaan om die 'sachgemäßen Kombination und theologische Deutung des Überlieferten, wobei immer die geschichtliche Zusammengehörigkeit den Vorrang hat vor der gedanklich-theologischen' (Von Rad 1969:129). Solank hulle op dieselfde gebeure betrekking het, kan van die wyduiteenlopendste materiaal denkbaar saamgevoeg wees. 'Eine der wesentlichsten Formen seines ganzen Theologisierens bestand also für Israel in der Verarbeitung, Kombination und aktualisierenden Interpretation dokumentarischer Überlieferungen' (Von Rad 1969:130). Soos wat elke geslag opnuut hulleself in die lig van die tradisie as Israel moes leer verstaan, het die oorlewering aangegroei deur aanvulling by die ouer materiaal, herrangskikking en interpretasie daarvan. Hierin was 'n wet van 'theologischer Dialektik' (Von Rad 1969:133) werksaam '... das Überkommene durch eine merkwürdige gegensätzlich formulierte Auffassung in Schwebe zu halten oder zu korrigieren' (Von Rad 1969:133). Dit skep 'n polariteit tussen uitsprake wat deur hulle parallelisme 'n verdere teologiese besinning aanbied. Hierdie struktuur probeer Von Rad in 'n teologie van die Ou Testament tot sy reg laat kom.

Reeds in die grondcredo van Deuteronomium 26:5v en die ander 'älteren geschichtlichen Summarien' (Von Rad 1969:143) is die gegewens ganz gleichrangig nebeneinander (Von Rad 1969:143; my beklemtonig) gestel. Daar was geen poging om hoogtepunte uit te lig nie. Die gebruik van oorleweringskomplekse wat van so 'n uiteenlopende aard en van verskillende teologiese gewig was om hierdie geskiedenis uit te beeld, het dit noodwendig gemaak dat daar 'n 'gewisse Gliederung, eine Periodisierung dieser Geschichte' (Von Rad 1969:143) sou wees. Deur hierdie 'periodisering' word 'jetzt ganz bestimmte theologische Bezüge der einzelnen Epochen zueinander deutlich, wovon die alten Summarien noch nichts angedeutet haben' (Von Rad 1969: 143). Met hierdie 'periodisering' bedoel Von Rad dan die tema of die teologiese metafoor wat gevorm word deur die jukstaponering van die materiaal. Die insig van Von Rad is dat hierdie 'periodisering' aan die hand van die verbondsluiting met Jahwe onderneem is. So word duidelik dat die verbondsluiting met Abraham en die verbondsluiting met Moses by Sinai 'dem ganzen jehovistischen Werk das Profil geben' (Von Rad 1969:147). Ook die Priesterskrif is rondom 'n verbondsteologie opgebou. Deur die byeenvoeging van $\mathrm{P}$ aan JE is nog verdere aksente aan die verbondsteologie gevoeg. Die oorgelewerde materiaal in die eindstadium van die Heksateug word dus geperiodiseer rondom verbond sodat die geskiedenis 'n relaas word van 'n verbond wat God sluit en wat uiteindelik uitloop op volkswording en landbesitneming.

In die geskiedenis van Abraham tot by Josef kom daar nie uitdruklike interpretasies van die geskiedenis deur die verteller voor nie. Sy kommentaar kan slegs op indirekte wyse afgelees word. Reeds 'geformt überkommenen Sageneinheiten' (Von Rad 1969: 
179) kan daarin van dele onderskei word waaragter daar nie 'n ou oorlewering staan nie en wat slegs as 'verbindende Teile' (Von Rad 1969:179) diens doen. Dit is in hierdie verbindende dele waarin die opvatting van die verteller die duidelikste gesien kan word. Hulle is egter gering in aantal en toon slegs kleiner vertellingssamehange aan en nie die van die hele aartsvadervertelling nie. Die betekenis van die vertelling moet eerder uit die samehang van die geheel afgelees word. Die geheel is opgebou uit stukke materiaal wat van verskillende oorsprong is en uit verskillende gebiede van Israel afkomstig is. 'Dieser Aufbau der Vätergeschichte aus vielerlei ursprünglich selbständigen Überlieferungsstücken enthält aber auch in biblisch-theologischer Hinsicht Bedeutsames' (Von Rad 1969:180). In die bont vertellingsmosaiek van materiaal wat in die planmatige 'Überarbeitungsprozess' bymekaar gevoeg is, is daar 'ein tragendes, verbindendes Gerüst' (Von Rad 1969:181) van Goddelike beloftes. Hierdie tema wat as verbinding gebruik is, kom nie net in die materiaal voor waarin dit oorspronklik teenwoordig was nie, maar is ook 'in solche Einheiten nachträglich eingelegt worden, denen sie ursprünglich fremd war und die durch sie inhaltlich verändert, bereichert wurden' (Von Rad 1969:181). Die onderskeie vertellingskomplekse het 'eine überraschend abwechslungreiche Thematik' (Von Rad 1969:184) wat onder die oorhoofse boog van belofte en vervulling in die aartsvaderverhale en die Heksateug saamgevat is.

Die veelvoud van tradisies wat in die vertelling van die Rietseegebeure gebruik is, toon aan dat hierdie '... Heilsereignis theologisch nicht eindeutig war ...' (Von Rad 1969:192). Elkeen van die tradisies wat gebruik is, dra uit 'n ander hoek iets by om iets besonders en aanskoulik van die verlossingsdaad by die Rietsee te beklemtoon.

Eksodus 19:1 tot Numeri 10:10 vorm 'n 'Überlieferungskomplex abnormalen Umfangs' (Von Rad 1969:200). Dit is 'n 'unförmige Traditionsballung' (Von Rad 1969: 201) van die wyduiteenlopendste materiaal met die 'grössten Unterschiede' (Von Rad 1969:201) waarin daar tevergeefs na 'n verbindende teologiese lyn gesoek word. Wat die ineengroei van die tradisies hierin bepaal het was suiwer net die gemeenskaplike lokaliteit (Sinaï) en die persoon van Moses. Verskillende stukke materiaal het rondom hierdie temas saamgekom en is met tyd '... völlig asyndetisch aneinandergereiht worden ...' (Von Rad 1969:201). Hierdie oorleweringskompleks het vir ' $n$ lang tyd selfstandig bestaan. Dit is eers op 'n heelwat later stadium in die reeds bestaande gedeeltes oor die Kadesgebeure tussen ingevoeg, odat die vertelling oor Kades dit omraam.

Deuteronomium is ' $n$ kunstig opgeboude mosaiek van verskillende preke waarin historiese, kultiese en juridiese oorlewerings saamgevat is en met mekaar geharmoniseer is om 'n sinvolle samehangende werk te vorm (vgl Von Rad 1969:233-4).

Selfs in die materiaal wat op die Heksateug volg, vind Von Rad nog aanduidings van dieselfde proses. Die geskiedenis vanaf die besetting van die land is volgens hom nie op dieselfde manier 'bekenntnisbildend, bekenttniserweiterend' (Von Rad 1969: 318) hanteer nie. Dit is buite die raamwerk van die heilsgeskiedenis, wat teen hierdie 
tyd reeds kanonieke status geniet het, hanteer. Daar is nie meer 'unförmigen Traditionsballungen' (Von Rad 1969:318) nie. Daar word ook nie by bestaande belydende temas aangesluit nie. Hier word eerder met geskiedsdokumente en geskiedskrywing gewerk. Wat wel steeds aanwesig is, is 'Überarbeitungen und Verklammerungen, in denen ... eine neue Interpretation auf den Plan tritt' (Von Rad 1969:319). Hoewel die samestelling van materiaal veel deursigtiger en eenvoudiger is as in die Heksateug, het ons steeds hier met samestelling te doen, met wat Von $\operatorname{Rad}$ noem '.. jene mächtige Verklammerung ...' (Von Rad 1969:319). Die Deuteronomistiese Geskiedenis het sy materiaal rondom die koningskap van Dawid gebou. Alles word in terme daarvan verstaan. 'Diese Königtum hat nicht nur schlagartig aufs stärkste literaturbildend, sondern auch theologiebildend gewirkt' (Von Rad 1969:320). Ook hier is 'n 'Traditionsballung' (Von Rad 1969:320).

Ook in sy hantering van die groter geheel is dit duidelik dat Von Rad steeds in montage-terme gedink het. Hoewel hy Israel se belydenis vanaf sy vroegste stadia nagevors het, is dit tegelyk ook so dat Von Rad '... dramatically brought to light the fact that the final stages of Israel's faith also contained much of interest to biblical theology' (Sailhamer 1995:215). Dit is veral die 'Endgestalt des Textes' (Crenshaw 1979:27) wat vir Von Rad van teologiese belang is. Die beloftegeskiedenis-model waarmee hy werk, bring mee dat hy die Ou Testament sien as 'n boek van 'ständig wachsenden Erwartung' (Oehming 1985:24). Dit is onvermydelik dat die Nuwe Testament in die verlengstuk van hierdie voorstuwende verwagtings lê. Ou en Nuwe Testament sal uiteindelik op mekaar betrek moet word. Crenshaw plaas die saak in breër konteks wanneer hy sê: 'Ein besonderes Charakteristikum der Theologie Von Rads liegt in dem Versuch, die beiden Testamenten zusammenzubringen, ein Bemühen, daß man nicht völlig Von dem Kampf gegen den Nationalsozialismus und dessen Verachtung alles Jüdischen loslösen kann' (Von Rad 1979:34). Die hermeneutiese gevolg van die betrekking van die inhoude van die Testamente op mekaar, is: 'Zum vollen Verständnis eines Textes gehört die Kenntnis seiner Wirkungsgeschichte. D.h. erst vom Ganzen der Schrift, erst vom Ganzen des Kanons her, gewinnt der alttestamentliche Einzeltext seine wahre bedeutung' (Oehming 1985:24). Eers wanneer 'n teks uit die een Testament in jukstaposisie naas 'n teks uit die ander Testament geplaas word, kan by 'n metafoor, 'n Bybelse teologie, uitgekom word. Dit gaan saam met Von Rad se eiesoortige gebruik van die tegniek van tipologie.

Ook deur hierdie tegniek probeer hy die Testamente in verband bring. Binne die raamwerk van belofte en vervulling werk hy met tipes en teenstaande antitipes. In die voortgaande geskiedenis van die volk van God betrek hy mense en instellings op mekaar as jukstaponerende gegewens wat die metafoor van God se heilsgeskiedenis tot uitdrukking bring. Nêrens probeer Von Rad egter Nuwe-Testamentiese begrippe gebruik om die Ou Testament te verklaar nie. 'Niemals hätte ein Analogiedenken, daß das 
Alte Testament als einen Schatten des Neuen, das Neue als die Substanz des Alten bezeicnet, seine Anerkennung gefunden, den für ihn enthielten Altes und Neues Testament jeweils beides' (Crenshaw 1979:34-5). Albei staan as afgeronde selfstandige dele langs mekaar en vorm in hulle gesamentlikheid een teologiese metafoor.

Ook in sy teologiese denke gee Von Rad blyke van 'n jukstaponerende benaderingswyse. Hy verwys na die ineenvervlegting van die Sinaï- en Landnahmetradition en sê: 'In dieser Zusammenordnung der beiden Traditionen zeichen sich die beiden Grund-elemente aller biblischen Verkündigung ab: Gesetz und Evangelium' (Von Rad 1961:62). Vanuit sy Lutheraanse agtergrond dink hy in terme van die twee elliptiese pole van wet en evangelie. Uit daardie neweskikking van twee entiteite poneer hy die teologiese metafoor waarmee hy probleemoplossend en verkondigend na die wêreld van sy tyd wil gaan.

\section{SLOTSOM}

By al die kritiek wat daar mag wees teen Von Rad se tradisie-historiese benadering en sy onvermoë om tussen geskiedenis en heilsgeskiedenis te onderskei, leef sy aksentuering van kerugma en credo nog steeds voort in die moderne uitleg van die Ou Testament. Oehming het besondere waardering vir Von Rad se poging in sy Theologie des Alten Testaments om die teks van die Ou Testament self aan die woord te stel: 'Sie ist m.E. darin schlechterdings normativ, dass sie auf die verschiedenen alttestamentlichen Autoren mit ihrem je eigenen Wort hören lehrt, und nicht gewaltsam unhistorisch alle Stimmen über eine systematischen Einheitsleisten zieht' (Oehming 1985:78). Von Rad sluit in die genre van sy teologie ten nouste aan by die belydenisgenre van die Ou Testament waarmee hy werk. Hy probeer sy teologiese metafoor uitbou vanuit die teologiese metafore van die Bybel self. Daarin stel hy ' $n$ voorbeeld vir teologiese metafoorvorming vir elke geslag daarna.

Die wyse waarop Von Rad binne die historiese konteks van Duitsland met al sy konflikte, die Ou Testament bestudeer en nagevors het en sy resultate aan die kerk aangebied het, wys die weg aan vir dinamiese teologiebeoefening en belydenisvorming. 'Gerhard Von Rad verstand sich als christlicher Theologe. Die Überzeugung, daß die Stimme des alten Israel Von den christlichen Kirche gehört werden könnte und müsste, inspirierte sein Hören auf den biblischen Text' (Crenshaw 1979:168). Hy het op 'n kreatiewe wyse sin probeer gee aan 'n konflikterende wêreld deur 'n teologiese metafoor daar te stel wat aan die Ou Testament met sy kerugma en belydenis 'n staanplek gee binne 'n kerk wat onder radikale nuwe omstandighede steeds moes bly bely.

Die wyse waarop hy die diversiteit van die Ou Testament hanteer het en in verhouding tot die Nuwe Testament gestel het, bly nog steeds 'n rigtinggewende voorbeeld vir vandag. Die manier waarop hy die rasionaal van die tradisieproses probeer peil het 
deur dit as 'n montage-tipe tegniek te beskryf wat teologiese metafore vir een geslag na die ander opgelewer het, bly ' $n$ aansporing om ook in die beoefening van die teologie van vandag die moontlikheid te eksploiteer om deur middel van montage belydenisvormend met die $\mathrm{Ou}$ Testament en die Bybel om te gaan en selfs bestaande belydenisse montage naas nuwe belydenisse te lees en te verstaan. Afgesien van wat daar ook al vir of teen sy tradisie-historiese teorieë gesê word, bly sy werke 'n bewys dat die gedagte van montage as hermeneutiese sleutel om die Bybel te verstaan en ook daarmee byderwetse teologie te bedryf in 'n postmoderne wêreld, met sy holistiese en interaktiewe benadering, nie iets is wat ligweg afgemaak kan word nie.

\section{Literatuurverwysings}

Albrecht, R J 1992. Montage, mise en scène, and miserable acting: Feminist discourse in Donne's Holy Sonnet X. English Language Notes 29/4, 23-32.

Bakhuizen van den Brink, J N \& Dankbaar, W F 1968. Handboek der Kerkgeschiedenis, Vierde Deel: De Kerk sedert de seventiende eeuw. Den Haag: Berb Bakker.

Crenshaw, J L 1979. Gerhard Von Rad: Grundlinien seinen theologischen Werks. München: Chr Kaiser.

Holladay, H 1993. Out of Line: History, psychoanalysis, and Montage in H.D.'s

Long Poems. By Susan Edmunds. American Literature 68/1, 253-254.

Mueller, R 1987. Montage in Brecht. Theatre Journal 39/4, 473-486.

Oehming, M 1985. Gesamtbiblische Theologien der Gegenwart: Das Verhältnis von AT und NT in der hermeneutischen Diskussion seit Gerhard Von Rad. Stuttgart: Kohlhammer.

Preu, H D 1991. Theologie des Alten Testaments, Band 1: JHWS erwählendes Handeln. Stuttgart: Kohlhammer.

Prichard, R B 1990. Genre, metaphor, and theology, The interpreation of form and content in theological texts. Doctoral thesis Graduate Theological Union, Berkeley, California.

Renders, L 1983. Hugo Raes: Schrijven uit wanhoop. Spiegel der Letteren 25/1, 2842.

Sailhamer, J H 1995. Introduction to Old Testament Theology: A Canonical Approach. Grand Rapids, Michigan: Zondervan.

Sánchez-Biosca, V 1990. Montage and Spectator: Eisenstein and the avantgarde. Semiotica 81/3 \& 4, 277-289.

Sparke, W \& McKowen, C 1970. Montage: Investigations in Language. London: Collier-Macmillan.

Venter, P M 1987. Die kanongeskiedenis van die Ou Testament. Pretoria: Kital. Venter, P M 1991. Holisme en Totaliteit. HTS 47/4, 1088-1098. 
Von Rad, G 1961. Gesammelte Studien zum Alten Testament: Theologische Bücherei. Neudrucke und berichte aus den 20. Jahrhundert, Band 8 Altes Testament. München: Chr Kaiser Verlag.

Von Rad, G 1969. Theologie des Alten Testaments, Band I: Die Theolgie der geschichtliche Überlieferungen lsraels. München: Chr Kaiser Verlag. 